\title{
Proinflammatory Cytokines and Leptin Are Increased in Serum of Prepubertal Obese Children
}

\author{
A. Denizmen Aygun, ${ }^{1}$ Serdal Gungor, ${ }^{1}$ Bilal Ustundag, ${ }^{2}$ Metin K. Gurgoze, ${ }^{1}$ and Yasar Sen $^{1}$ \\ ${ }^{1}$ Department of Pediatrics, Medical Faculty, Firat University, 23119 Elazig, Turkey \\ ${ }^{2}$ Department of Biochemistry, Medical Faculty, Firat University, 23119 Elazig, Turkey
}

Received 20 January 2005; accepted 21 February 2005

\begin{abstract}
It has not yet been shown in prepubertal children how cytokines, leptin, and body mass, as well as parameters of obesity are interrelated. The aim of this study was to explore the relation between circulating levels of some cytokines with leptin and body mass index. A case control study was carried out in obese children of both sexes. An obese group was carried out with 63 school prepubertal children and a control group comprised the same number of nonobese children paired by age and by sex. Mean serum leptin concentration was significantly higher in the obese children at $19.9 \pm 7.4 \mathrm{ng} / \mathrm{mL}$, than the control group $(7.9 \pm 5.1 \mathrm{ng} / \mathrm{mL})$. Serum IL- $1 \beta$, IL-6, and TNF- $\alpha$ levels were also significantly higher in the obese group than controls $(33.0 \pm 8.9,45.2 \pm 11.8$, and $9.2 \pm 2.3 \mathrm{pg} / \mathrm{mL}$, versus $3.6 \pm 1.0,13.1 \pm 3.9$, and $3.9 \pm 1.0 \mathrm{pg} / \mathrm{mL}$, resp). In controversy, serum IL-2 level was diminished in the obese group as $0.4 \pm 0.1$ versus $0.9 \pm 0.1 \mathrm{U} / \mathrm{L}$. Obesity may be a low-grade systemic inflammatory disease. Obese prepubertal children have elevated serum levels of IL-1 $\beta$, IL-6, and TNF- $\alpha$ which are known as markers of inflammation.
\end{abstract}

\section{INTRODUCTION}

Obesity is an excessive accumulation of body fat and its gross manifestation poses a real threat to health and the prevalence in children has increased dramatically over the last 20-30 years in developed countries. It is a health risk frequently associated with complications such as type 2 diabetes, dyslipidemia, high blood pressure, abnormal fibrinolysis, and cardiovascular disease $[1,2,3]$.

Leptin, the product of the $o b$ gene, is a recently discovered proteohormone that is thought to play a key role in the regulation of body weight [4]. It is produced by the adipocytes to regulate food intake at a hypothalamic level, and its circulating levels directly correlate with the amount of body fat and body mass index (BMI). It is accepted that serum leptin levels reflect the extent of adiposity $[5,6]$. Leptin concentration is increased in most obese adults and children, indicating that such simple obese subjects are irresponsive to the lipostatic action of leptin $[7,8]$. Also leptin-deficient and leptin-receptor-deficient mice show an obese phenotype [9].

A number of proinflammatory cytokines, such as interleukin (IL)-1, IL-6, tumor necrosis factor (TNF)- $\alpha$, and interferon (IFN) $-\gamma$ have been proposed as mediators of the cachectic process [10]. Moreover, evidence has been provided that $o b$ gene expression may be up regulated by

Correspondence and reprint requests to A. Denizmen Aygun, Department of Pediatrics, Medical Faculty, Firat University, 23119 Elazig, Turkey; daugun@firat.edu.tr proinflammatory cytokines such as IL- 1 and TNF- $\alpha$, producing prompt, dose-dependent increases in serum leptin concentrations. Although it has recently been shown that TNF- $\alpha$ administration increases leptin expression and circulating concentrations in rodents, the activation of the TNF- $\alpha$ system may exert a significant influence over leptin levels in humans [11]. Production of acute-phase proteins is under control of macrophage-derivated cytokines, for example, IL- $1 \beta$, TNF- $\alpha$, and IL- 6 . These substances mediate not only inflammatory and immune reactions, but also the development of cachexia [12].

On the other hand, in children, higher inflammation levels in overweight and obese children predispose to disease at older age as myocardial infarction, peripheral arterial disease, ischemic stroke, and diabetes mellitus. However, in adults many factors correlated with obesity can cause higher inflammation levels including smoking, arthritis, and cardiovascular disease. But, association between obesity and inflammation in prepubertal children supports a direct relationship because the prevalence of smoking, atherosclerosis, and preexisting disease is low [13].

Further elucidation of the potential interaction between these two systems could provide important insights into the feedback system for regulation of body weight and the mechanisms leading to obesity and cachexia in humans. So far, it has not yet been shown in prepubertal children how cytokines, leptin, and body mass, as well as parameters of obesity are interrelated. The aim of this study was to explore the relation between circulating levels of some cytokines with leptin and body mass index. 


\section{SUBJECTS AND METHODS}

\section{Study design}

A case control study was carried out in obese children of both sexes. A child was considered obese when their body weight exceeded $120 \%$ of the standard body weight, which is defined as the mean body weight corresponding to the height for that age from national statistics for Turkish school children and when body mass index was over the 99th percentile in the growth curve for the study population [14], because this is the only limit that allows for the selection of markedly obese children.

An obese group was composed of 63 school prepubertal children and a control group comprised the same number of nonobese children paired by age and by sex. All subjects were at Tanner stage 1 . Children with primary hyperlipidemia, hypertension, diabetes or glucose intolerance, and secondary obesity and who received pharmacological agents were excluded. The study was approved by The Local Ethical Committee, and informed consent was given by parents.

Blood samples was drawn from children constituting obese and control groups, which was authorized by parents, at the visit of their school in the morning after overnight fast; at the same time, they were subjected to anthropometric measurements including height and weight. The serum was separated and kept frozen at $-24^{\circ} \mathrm{C}$ until analysis.

\section{Analytical measurements}

Body weight and body height were obtained from each subject by nurses using electrical scales and wall-mounted stadiometer. Body mass index was calculated as weight in kilograms divided by height in $\mathrm{m}^{2}$ and used as an index of nutritional status.

The tests from collected samples were carried out in the laboratory of the Department of Biochemistry. Serum leptin levels were determined with an enzyme-linked immunosorbent assay (ELISA) method using commercial kits (Leptin kit, DRG International, Inc, NJ) and the sensitivity of detection level was $7.2 \mathrm{pg} / \mathrm{mL}$. Serum concentrations of cytokines such as IL-1 $\beta$, IL-2, IL- 6 , and TNF- $\alpha$ were measured using commercially available ELISA kits (ELISA, Pharmingen Inc, San Diego, Calif) and the sensitivity of detection for IL- $1 \beta$, IL-2, IL- 6 , and TNF- $\alpha$ was $3.5 \mathrm{pg} / \mathrm{mL}, 0.02 \mathrm{U} / \mathrm{L}, 2.1 \mathrm{pg} / \mathrm{mL}$, and $1.8 \mathrm{pg} / \mathrm{mL}$, respectively. All of the serum samples were analyzed in duplicate with a range less than $10 \%$.

\section{Statistical analysis}

Values are expressed as mean \pm SD. All calculation was made with the statistical program SPSS version 10.0 on an IBM compatible computer. All the main study variables were positively skewed and therefore transformed and used.

In order to compare the obese and the control group with respect to leptin, cytokines, height SDS, and BMI
TABle 1. Characteristics of subjects.

\begin{tabular}{lllc}
\hline Variables & $\begin{array}{l}\text { Obese } \\
n=63\end{array}$ & $\begin{array}{l}\text { Control } \\
n=63\end{array}$ & $P$ \\
\hline Age (years) & $8.8 \pm 1.2$ & $8.9 \pm 1.0$ & NS \\
Gender $(\mathrm{M} / \mathrm{F})$ & $26 / 37$ & $26 / 37$ & - \\
Weight $(\mathrm{kg})$ & $45.2 \pm 2.8$ & $3.19 \pm 1.4$ & $<.001$ \\
Height $(\mathrm{cm})$ & $137.2 \pm 1.4$ & $134.9 \pm 1.0$ & NS \\
BMI $\left(\mathrm{kg} / \mathrm{m}^{2}\right)$ & $24.0 \pm 4.0$ & $17.5 \pm 2.3$ & $<.001$ \\
\hline
\end{tabular}

TABLe 2. Serum cytokines and leptin concentrations.

\begin{tabular}{lccc}
\hline Variables & $\begin{array}{l}\text { Obese } \\
n=63\end{array}$ & $\begin{array}{l}\text { Control } \\
n=63\end{array}$ & $P$ \\
\hline Leptin $(\mathrm{ng} / \mathrm{mL})$ & $19.9 \pm 7.4$ & $7.9 \pm 5.1$ & $<.001$ \\
IL-1 $\beta(\mathrm{pg} / \mathrm{mL})$ & $33.0 \pm 8.9$ & $3.6 \pm 1.0$ & $<.001$ \\
IL-2 $(\mathrm{U} / \mathrm{L})$ & $0.4 \pm 0.1$ & $0.9 \pm 0.1$ & $<.01$ \\
IL-6 $(\mathrm{pg} / \mathrm{mL})$ & $45.2 \pm 11.8$ & $13.1 \pm 3.9$ & $<.001$ \\
TNF- $\alpha(\mathrm{pg} / \mathrm{mL})$ & $9.2 \pm 2.3$ & $3.9 \pm 1.0$ & $<.001$ \\
\hline
\end{tabular}

SDS, one-way analysis of variance (ANOVA) and Tukey B and Scheffe (post-ANOVA) tests were used and a $P$ value $<.05$ was considered significant.

The relationships between the data of the study and the control groups were investigated by Pearson's correlation.

\section{RESULTS}

The characteristics of obese and control group children are listed in Table 1. The two groups did not differ significantly in age, gender, and height. The mean BMI was $24.0 \pm 4.0 \mathrm{~kg} / \mathrm{m}^{2}$ in the obese group and was $17.5 \pm 2.3 \mathrm{~kg} / \mathrm{m}^{2}$ in the control group; the difference was statistically significant $(P<.001)$.

Serum cytokines and leptin values in the two groups are listed in Table 2. Mean plasma leptin concentration was significantly higher in the obese children at $19.9 \pm$ $7.4 \mathrm{ng} / \mathrm{mL}$ in comparison to the control children at $7.9 \pm$ $5.1 \mathrm{ng} / \mathrm{mL}(P<.001)$. Serum leptin concentrations were in correlation with BMI in obese children $(r=0.651$, $P<.001)$. Serum IL- $1 \beta$, IL-6, and TNF- $\alpha$ levels were also significantly higher in the obese group than the control group $(33.0 \pm 8.9,45.2 \pm 11.8$, and $9.2 \pm 2.3 \mathrm{pg} / \mathrm{mL}$, versus $3.6 \pm 1.0,13.1 \pm 3.9$, and $3.9 \pm 1.0 \mathrm{pg} / \mathrm{mL}$, resp; $P<.001$ ). In a controversy, serum IL-2 level was significantly lower in the obese prepubertal children than the control group $(0.4 \pm 0.1$ versus $0.9 \pm 0.1 \mathrm{U} / \mathrm{L})$.

In obese children, serum leptin levels were positively correlated with serum IL-1 $\beta$, IL-6, and TNF- $\alpha$ levels $(r=$ $0.563, P<.01, r=0.377$, and $r=0.418, P<.05$, resp) and inversly correlated with serum IL-2 $(r=-0.471$, $P<.01)$ level. There was no correlation between cytokines level of obese children, simply between IL- 6 and TNF- $\alpha$ $(r=0.395, P<.05)$. 


\section{DISCUSSION}

The etiology of obesity represents a complex interaction of genetics, diet, metabolism, and physical activity levels. Leptin levels correlate with adiposity, decrease actually with caloric restriction, and increase with refeeding. The brain is an established critical site of leptin function [15].

In the larger Chard longitudinal study of leptin levels and body composition in normal children, it was observed that leptin levels rose gradually with age in both boys and girls until the onset of puberty. However there was a wide variation in leptin levels at the onset of puberty, so the level of this threshold may differ greatly between individuals [16].

Serum leptin levels were found by Kirel et al [17] higher to be in obese children than in those normal weighted. Also strongly correlated with BMI are skinfold thickness and body weight as described previously in adults and adolescents. It was hypothesized that leptin is delivered to the brain by a saturable transport system. A decreased capacity to transport leptin to the brain via cerebrospinal fluid has already been shown in obese humans despite having higher leptin concentrations than those found in lean individuals. This is another mechanism that may provide an explanation for leptin resistance in obese children [18]. In our study, also serum leptin levels were revealed to be higher in obese prepubertal children than in the control group and were well correlated with BMI.

On the other hand obesity has been associated with higher inflammation levels in adults. However, many factors correlated with obesity can cause higher inflammation levels, including smoking, arthritis, cardiovascular disease, and diabetes mellitus. The recent findings of an association between obesity and inflammation in prepubertal children support a direct relationship because the prevalence of smoking, atherosclerosis, and preexisting disease is low in children [13].

In this study, serum IL- $1 \beta$ and serum TNF- $\alpha$ levels were detected to be higher in prepubertal obese children than healthy normal-weighted subjects. However, serum IL-2 and IL-6 levels were higher in healthy subjects. These serum cytokines levels were well correlated with serum leptin levels and BMI. In a study on children with diabetes mellitus type 1 , the authors showed that the serum concentration of IL- $1 \beta$, IL- 2 , IL- 6 , and TNF- $\alpha$ was significantly correlated with leptin which was determined by the excess of adiposity [19].

TNF- $\alpha$ is a proinflammatory cytokine that involves the production of other cytokines, such as IL-1 and IL6. Several cytokines, such as IL- $1 \alpha$, IL- 6 , and TNF- $\alpha$, by increasing hypothalamic CRH gene expression, may activate the same $\mathrm{CRH}$ pathway as the leptin-catabolic effector system. Considering that leptin receptor is a member of the class I cytokine receptor family and that leptin activates intracellular signal transduction pathways common in many cytokines, the proinflammatory ones act as leptin-like factors and mimic the effectors leptin, decreasing energy intake and increasing energy expenditure [20]. The same cytokines raise leptin in rodents [11]. SantosAlvares et al [21] found that leptin stimulating the proliferation of human circulating monocytes increases the production of IL- 6 , and to a lesser extent TNF- $\alpha$ supporting a hypothetic role of leptin as a new proinflammatory cytokine. Loffreda et al [22] showed that leptin enhances the synthesis of proinflammatory cytokines by cultured macrophages.

The relationship of the TNF- $\alpha$ system to energy and metabolic homeostasis is potentially complex. On the one hand, increased levels of TNF- $\alpha$ have been associated with weight loss, hypermetabolism, and increased resting energy expenditure as measured by indirect calorimetry in several disease stocks, and administration of TNF- $\alpha$ is capable of producing some of these effects [23]. On the other hand, increased TNF- $\alpha$ expression in adipose cells is seen in obesity and has been linked to the development of insulin resistance [22]. First activation of the TNF- $\alpha$ system has been associated with increased energy expenditure and weight loss in humans. The association between serum leptin and TNF- $\alpha$-R 55 levels raises the intriguing possibility that the TNF- $\alpha$ system may act through the leptin system to increase energy expenditure and thereby induce weight loss in humans [23]. Second, it is well recognized that neuroendocrine function is subject to regulation by the immune system in humans, and it has recently been shown that leptin is a potent mediator of the neuroendocrine response in mice [11]. Thus, these data raise the possibility that one or more effects of the immune system on neuroendocrine function could, in addition to direct effects by cytokines on the central nervous system, be mediated through changes of the leptin system [21].

Cytokine secretion within adipocytes appears similar to that of other cells. There is general agreement that circulating TNF- $\alpha$ and IL- 6 concentrations are mildly elevated in obesity. Most studies suggest that increased TNF$\alpha$ mRNA expression or secretion in vitro in adipose tissue appears to include usual inflammatory stimuli such as lipopolysaccaride, the size of the fat cells per se, and catecholamine. The effects of cytokines within adipose tissue include some actions that might be characterized as metabolic. TNF- $\alpha$ and IL- 6 inhibit lipoprotein lipase and TNF- $\alpha$ additionally stimulates hormone-sensitive lipase and induces uncoupling protein expression [24].

Children and adolescents with obesity accompanied by hypertension and diabetes have elevated levels of IL6 and TNF- $\alpha$. IL- 6 and TNF- $\alpha$ correlates with body mass index not only in obese but also in hypertensive, slim children. The elevated levels of cytokines (IL-6, TNF- $\alpha$ ) in children with atherosclerosis risk factors (particularly obesity) can confirm the presence of inflammatory process in early phases of atherosclerosis [25].

Leptin, by enhancing IL-1 concentrations, may pose proinflammatory actions, whereas neurotransmitters such as serotonin, dopamine, and neuropeptide $Y$ show anti-inflammatory actions by inducing 
acetylcholine release, which in turn suppresses the production of proinflammatory cytokines [26].

In conclusion, obesity may be a low-grade systemic inflammatory disease. Obese prepubertal children have elevated serum levels of IL- $1 \beta$, IL- 6 , TNF- $\alpha$, and leptin which are known as markers of inflammation. These results may contribute to the increased risk of diabetes and heart diseases in obese children.

\section{REFERENCES}

[1] Al-Malki JS, Al-Jaser MH, Warsy AS. Overweight and obesity in saudi females of childbearing age. Int J Obes Relat Metab Disord. 2003;27(1):134-139.

[2] Shigeta H, Shigeta M, Nakazawa A, Nakamura N, Yoshikawa T. Lifestyle, obesity, and insulin resistance. Diabetes Care. 2001;24(3):608-611.

[3] Troiano RP, Flegal KM, Kuczmarski RJ, Campbell SM, Johnson CL. Overweight prevalence and trends for children and adolescents. The National Health and Nutrition Examination Surveys, 1963 to 1991. Arch Pediatr Adolesc Med. 1995;149(10):1085-1091.

[4] Zhang Y, Proenca R, Maffei M, Barone M, Leopold L, Friedman JM. Positional cloning of the mouse obese gene and its human homologue. Nature. 1994;372(6505):425-432.

[5] Campfield LA, Smith FJ, Guisez Y, Devos R, Burn P. Recombinant mouse ob protein: evidence for a peripheral signal linking adiposity and central neural networks. Nature. 1995;269(5223):546-549.

[6] Lonnqvist F, Wennlund A, Arner P. Relationship between circulating leptin and peripheral fat distribution in obese subjects. Int J Obes Relat Metab Disord. 1997;21(4):255-260.

[7] Nakane T, Asayama K, Hayashibe H, Uchida N, Kodera K, Dobashi K. Changes in serum leptin concentration during behavioral therapy in obese children. Endocr J. 1999;46(5):703-709.

[8] Hassink SG, Sheslow DV, de Lancey E, Opentanova I, Considine RV, Caro JF. Serum leptin in children with obesity: relationship to gender and development. $\mathrm{Pe}$ diatrics. 1996;98(pt 1):201-203.

[9] Glaum SR, Hara M, Bindokas VP, et al. Leptin, the obese gene product, rapidly modulates synaptic transmission in the hypothalamus. Mol Pharmacol. 1996;50(2):230-235.

[10] Mantovani G, Maccio A, Madeddu C, et al. Serum values of proinflammatory cytokines are inversely correlated with serum leptin levels in patients with advanced stage cancer at different sites. J Mol Med. 2001;79(7):406-414.

[11] Grunfeld C, Zhao C, Fuller J, et al. Endotoxin and cytokines induce expression of leptin, the ob gene product, in hamsters. J Clin Invest. 1996;97(9):21522157.
[12] Tracey KJ. Tnf and other cytokines in the metabolism of septic shock and cachexia. Clin Nutr. 1992;11:1-11.

[13] Visser M. Higher levels of inflammation in obese children. Nutrition. 2001;17(6):480-481.

[14] Neyzi O, Yalcindag A, Alp H. Heights and weights of Turkish children. J Trop Pediatr Environ Child Health. 1973;19(1):5-13.

[15] Das UN. Is obesity an inflammatory condition? $\mathrm{Nu}$ trition. 2001;17(11-12):953-966.

[16] Ahmed ML, Ong KK, Morrell DJ, et al. Longitudinal study of leptin concentrations during puberty: sex differences and relationship to changes in body composition. J Clin Endocrinol Metab. 1999;84(3):899905.

[17] Kırel B, Doğruel N, Akgün N, Kılıç FS, Tekin N, Uçar B. Serum leptin levels during childhood and adolescence: relationship with age, sex, adiposity and puberty. Turk J Pediatr. 1999;41(4):447-455.

[18] Caro JF, Kolaczynski JW, Nyce MR, et al. Decreased cerebrospinal-fluid/serum leptin ratio in obesity: a possible mechanism for leptin resistance. Lancet. 1996;348(9021):159-161.

[19] Lo HC, Lin SC, Wang YM. The relationship among serum cytokines, chemokine, nitric oxide, and leptin in children with type 1 diabetes mellitus. Clin Biochem. 2004;37(8):666-672.

[20] Fruhbeck G, Jebb SA, Prentice AM. Leptin: physiology and pathophysiology. Clin Physiol. 1998;18(5):399-419.

[21] Santos-Alvarez J, Goberna R, Sanchez-Margalet V. Human leptin stimulates proliferation and activation of human circulating monocytes. Cell Immunol. 1999;194(1):6-11.

[22] Loffreda S, Yang SQ, Lin HZ, et al. Leptin regulates proinflammatory immune responses. FASEB J. 1998;12(1):57-65.

[23] Mantzoros CS, Moschos S, Avramopoulos I, et al. Leptin concentrations in relation to body mass index and the tumor necrosis factor-alpha system in humans. J Clin Endocrinol Metab. 1997;82(10):34083413.

[24] Cederholm T, Wretlind B, Hellström K, et al. Enhanced generation of interleukins 1 beta and 6 may contribute to the cachexia of chronic disease. Am J Clin Nutr. 1997;65(3):876-882.

[25] Glowinska B, Urban M. Selected cytokines (IL-6, IL8, IL-10, MCP-1, TNF-alpha) in children and adolescents with atherosclerosis risk factors: obesity, hypertension, diabetes. Wiad Lek. 2003;56(3-4):109116.

[26] Borovikova LV, Ivanova S, Zhang $M$, et al. Vagus nerve stimulation attenuates the systemic inflammatory response to endotoxin. Nature. 2000;405(6785):458-462. 


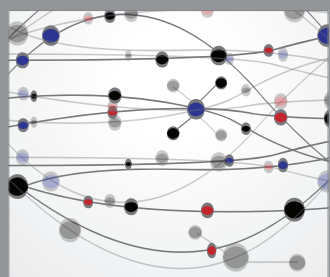

The Scientific World Journal
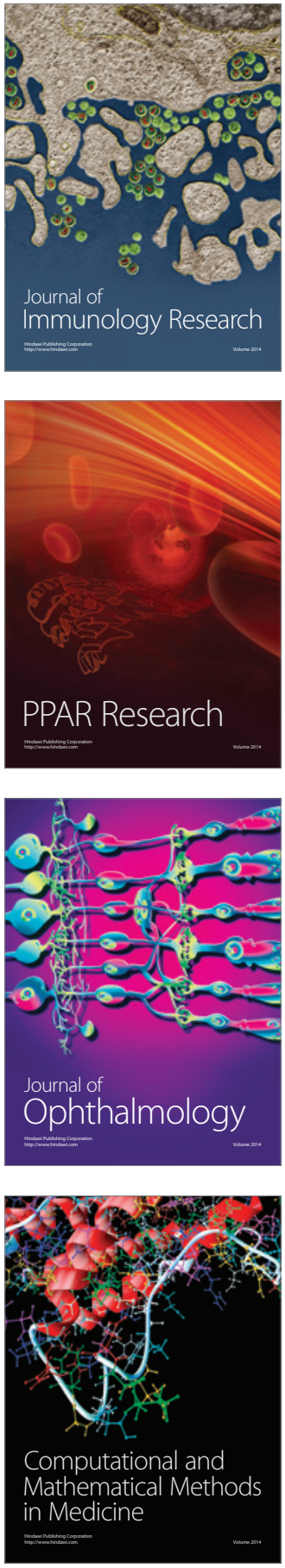

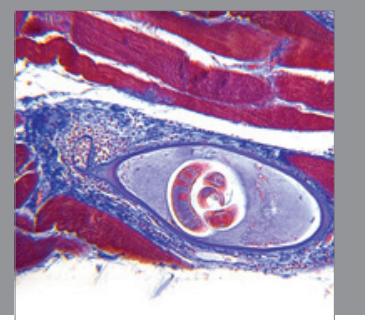

Gastroenterology

Research and Practice
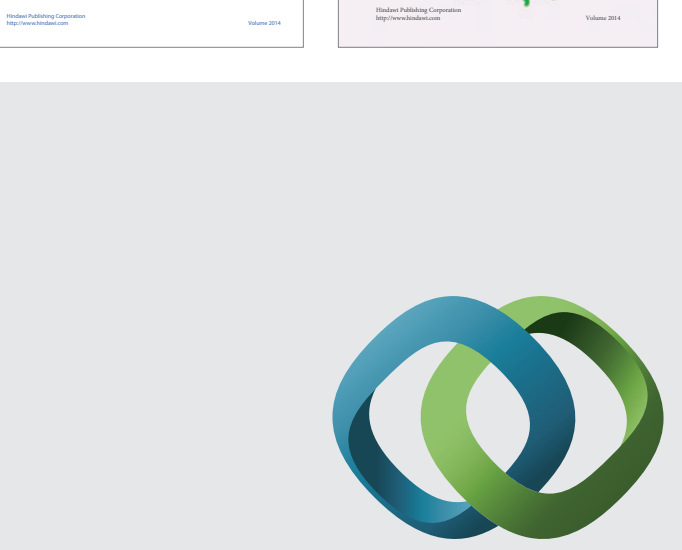

\section{Hindawi}

Submit your manuscripts at

http://www.hindawi.com
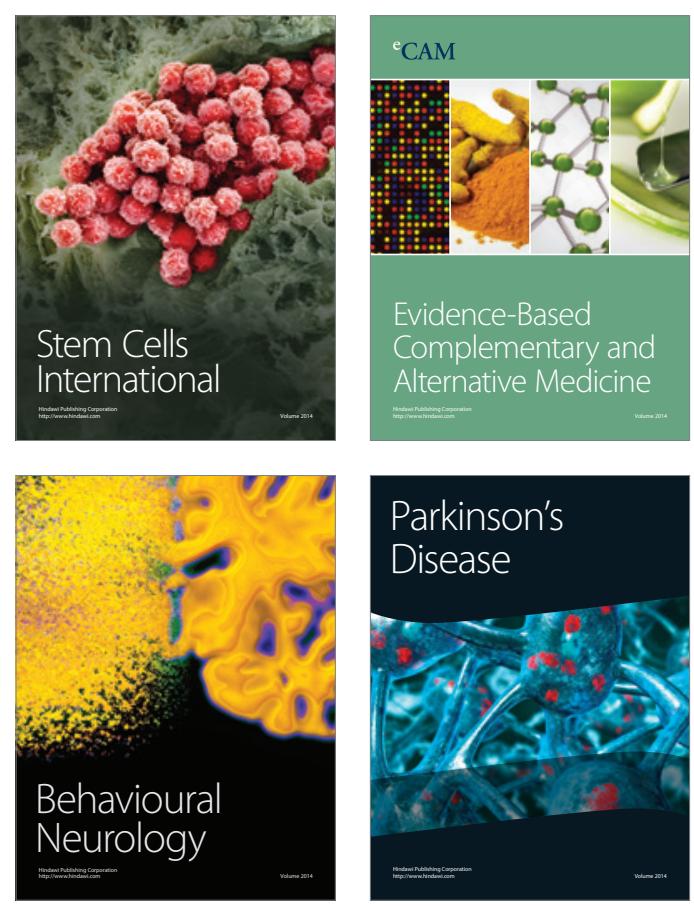

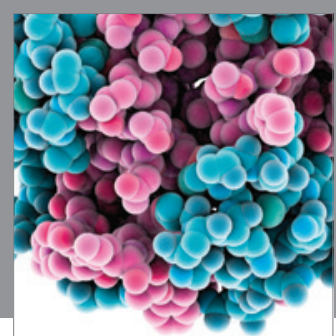

Journal of
Diabetes Research

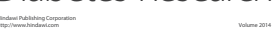

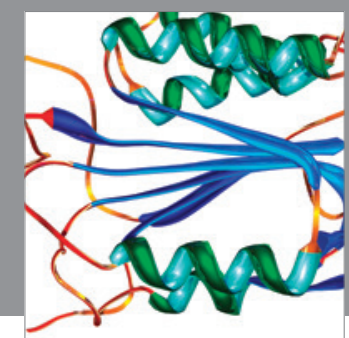

Disease Markers
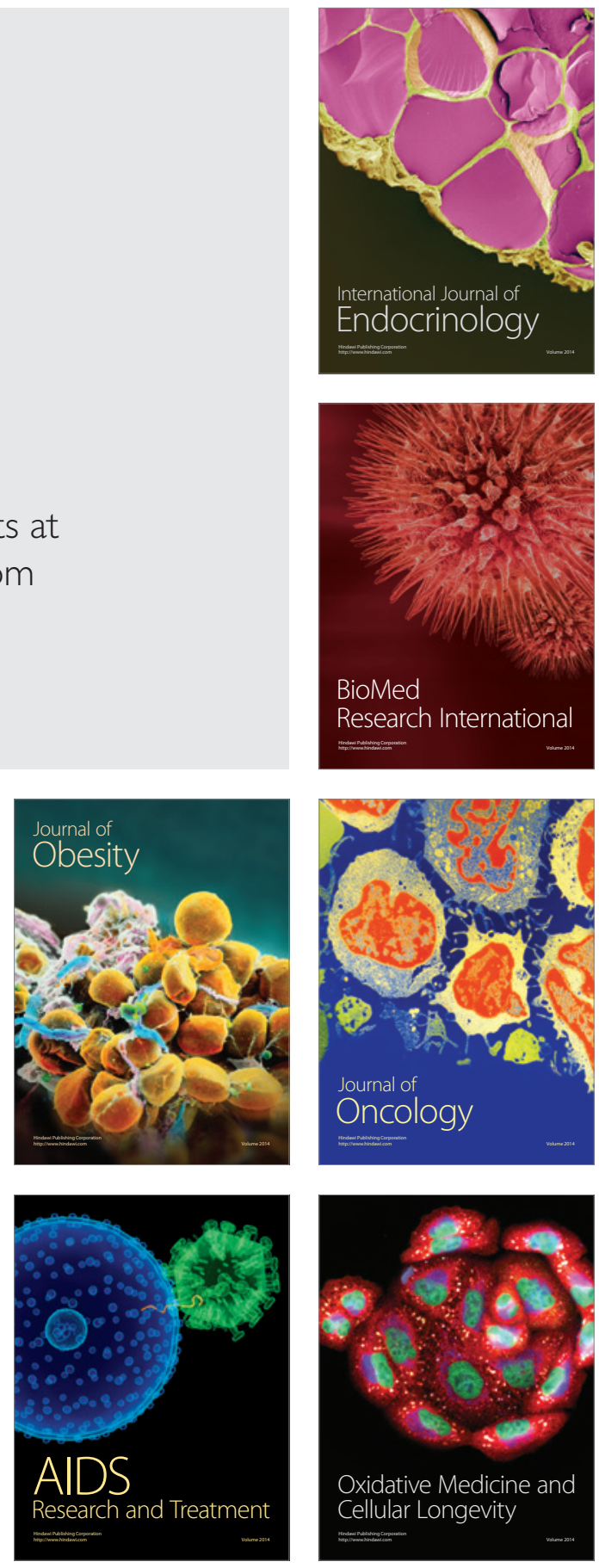